\title{
Changes in Physical Capability of 6 and 7 Year Old Students after Applying the Game Approach
}

\author{
Dao Chanh Thuc* \\ Department of Physical Education, An Giang University, Vietnam
}

Submission: May 10, 2018; Published: May 17, 2018

*Corresponding author: Dao Chanh Thuc, Department of Physical Education, An Giang University, Vietnam, Tel: +84985627686,

Email: thuchus@gmail.com; daochanhthuc@gmail.com

Abstract

The aim of the present research is to establish and compare the changes in the indicators, which give information about the physical development level of 6 and 7 years old students after applying the game approach in the mini basketball education field. This requires the following tasks:

a) To establish the level of the researched indicators of the physical development of 6 and 7 years old students before the experimental impact

b) To trace and compare the changes, which occurred in the examined groups after applying the game approach in the mini basketball education field

c) To establish the rise in the average levels of the examined indicators in the experimental groups after the pedagogical experiment a significant rise in all five of the examined indicators is observed in the three groups.

Keywords: Physical Capability; Students; Basketball; Game Approach

\section{Introduction}

The factors which define the motor features are anatomical, physiological, biochemical and pure psychological factors. When it comes to anthropometrical features such as height, weight and other physical signs, only then it can be said that the features are "physical" [1]. The physical features can be called motor when it comes to the central neural regulation mechanism for the movement management. They can be called psychomotor when it comes to the distinction of the quality feature of the motor activity from the perspective of the psychological factors [2]. Depending on the individual approach of different authors towards the definition of the term physical capability, various definitions of its content as well as the terminological variety regarding its explanation-physical preparedness, physical performance, physical readiness and etc. can be traced $[3,4]$.

A lot of contemporary authors think that in the modern stage of the basketball development, organized activities should begin at the age of 6-7 [1]. It is established that by the means of the sport practice children successfully apply the foundation of the basketball game through the so called "baby basketball", whose regulations and equipment, are well-adapted to the anatomical- physiological features of the kids. The aim of the activities is diversification and enrichment of the palette of impact in the process of the child's motor development in the form of a game, similar to the basketball by the means of the physical education. Thanks to the reinforcement in the last years of the lowest age in the mini basketball - the so called "baby basketball", it becomes clear that direction of teachers, coaches and of course parents towards the lowering of the age boundary for selection is required. Moreover the anatomy and physiology development as well as the psychological and pedagogical characteristics of the children in the early school age allow that [5].

\section{Purpose of the study}

The aim of the current research is to establish and compare the changes in the indicators which give information about the physical capability of 6 and 7 years old students after applying the game approach of mini basketball education. These are the following tasks:

a) To establish the level of the examined indicators regarding the physical capability of 6 and 7 years old students before the experimental influence 
b) To trace and compare the changes, which have occurred in the examined groups after applying the game approach of mini basketball education

c) To establish the rise in the average levels of the examined indicators in the experimental groups

\section{Methods}

Subject of the research are the signs of physical capability of 6 and 7 years old students. Object of the research is the initial mini-basketball education. Contingent of the research are 6 and 7 years old students, divided equally - 15 in each age - who are participating in the mini-basketball activities. The experimental groups take part in mini-basketball education by the means of the game approach. The game forms are picked up purposefully according to the anatomic, physiologic and the psycho-pedagogical features of the students as well as according to the set goals in the education [6,7]. The research is conducted in one school year.

\section{Mathematical and statistical processing of the data}

The mathematical and the statistical processing of the data from the testing are done on a personal computer with the help of the standard programs SPSS 20.0 and Microsoft Excel. The following mathematical and statistical methods are applied:
a) Variational analysis
b) Graphical analysis
c) Comparative analysis (t-criteria)

\section{Results}

The results after statistical expertise of the data (Tables 1 $\& 2$ ). They have been gathered by tests, which give information about the physical capability of 6 and 7 years old students, who are participating in the mini-basketball activities. On Figure 1 the rises of the average levels of the observed indicators of all the groups after the applied influence are shown.

Table 1: Average values and variability of the signs of the physical capability of the 6 year olds during the experiment

\begin{tabular}{|c|c|c|c|c|c|c|c|c|c|}
\hline Parameters Indicators & $\begin{array}{l}\text { Start - End } \\
\text { Examination }\end{array}$ & $\mathbf{X}$ & $\sigma$ & V\% & As & Ex & d & t & $\mathbf{P}$ \\
\hline Long jump with two legs (cm) & $\begin{array}{l}\text { I } \\
\text { II }\end{array}$ & $\begin{array}{l}121.87 \\
127.07\end{array}$ & $\begin{array}{l}12.03 \\
11.24\end{array}$ & 11.569 .12 & 0.670 .73 & $\begin{array}{l}-24 \\
-37\end{array}$ & 5.2 & 5.75 & 0.01 \\
\hline Vertical jump with two legs (cm) & $\begin{array}{l}\text { I } \\
\text { II }\end{array}$ & $\begin{array}{l}182.13 \\
212.31\end{array}$ & $\begin{array}{l}13.49 \\
23.69\end{array}$ & 7.0712 .86 & -0.500 .16 & $\begin{array}{r}0.73 \\
-0.05\end{array}$ & 30.18 & 4.4 & 0.01 \\
\hline $10 \mathrm{~m}$ sprint (high start) (s) & $\begin{array}{l}\text { I } \\
\text { II }\end{array}$ & $\begin{array}{l}2.98 \\
2.67 \\
\end{array}$ & $\begin{array}{l}0.19 \\
0.21\end{array}$ & 6.137 .32 & $\begin{array}{l}-0.46 \\
-0.52 \\
\end{array}$ & $\begin{array}{l}-1.3 \\
-2.2 \\
\end{array}$ & -0.31 & 10.14 & 0.01 \\
\hline Solid ball throwing - $1 \mathrm{~kg}(\mathrm{~cm})$ & $\begin{array}{l}\text { I } \\
\text { II }\end{array}$ & $\begin{array}{l}364 \\
379 \\
\end{array}$ & $\begin{array}{c}99.11 \\
101.16\end{array}$ & 24.3025 .26 & 0.630 .89 & 1.171 .96 & 14.87 & 8.63 & 0.01 \\
\hline Depth of the slope $(\mathrm{cm})$ & $\begin{array}{l}\text { I } \\
\text { II }\end{array}$ & $\begin{array}{l}96.07 \\
98.27\end{array}$ & $\begin{array}{c}7.5 \\
7.43\end{array}$ & 7.497 .34 & $\begin{array}{l}-0.28 \\
-0.18\end{array}$ & $\begin{array}{l}-1.49 \\
-1.36\end{array}$ & 2.2 & 6.87 & 0.01 \\
\hline
\end{tabular}

Table 2: Variability and significance of the rises in the average levels of the indicators for physical Capability of the 7 years old for the time of the experiment.

\begin{tabular}{|c|c|c|c|c|c|c|c|c|c|}
\hline Parameters Indicators & $\begin{array}{l}\text { Start - End } \\
\text { Examination }\end{array}$ & $\mathbf{X}$ & $\sigma$ & V\% & As & Ex & d & $\mathbf{t}$ & $\mathbf{P}$ \\
\hline Long jump with two legs (cm) & $\begin{array}{l}\text { I } \\
\text { II }\end{array}$ & $\begin{array}{l}121.87 \\
127.07\end{array}$ & $\begin{array}{l}12.03 \\
11.24\end{array}$ & 11.569 .12 & 0.670 .73 & $\begin{array}{l}-24 \\
-37\end{array}$ & 5.2 & 5.75 & 0.01 \\
\hline Vertical jump with two legs $(\mathrm{cm})$ & $\begin{array}{l}\text { I } \\
\text { II }\end{array}$ & $\begin{array}{l}182.13 \\
212.31\end{array}$ & $\begin{array}{l}13.49 \\
23.69\end{array}$ & 7.0712 .86 & -0.500 .16 & $\begin{array}{r}0.73 \\
-0.05\end{array}$ & 30.18 & 4.4 & 0.01 \\
\hline $10 \mathrm{~m}$ sprint (high start) (s) & $\begin{array}{l}\text { I } \\
\text { II }\end{array}$ & $\begin{array}{l}2.98 \\
2.67\end{array}$ & $\begin{array}{l}0.19 \\
0.21\end{array}$ & 6.137 .32 & $\begin{array}{l}-0.46 \\
-0.52 \\
\end{array}$ & $\begin{array}{l}-1.3 \\
-2.2 \\
\end{array}$ & -0.31 & 10.14 & 0.01 \\
\hline Solid ball throwing - $1 \mathrm{~kg}(\mathrm{~cm})$ & $\begin{array}{l}\text { I } \\
\text { II }\end{array}$ & $\begin{array}{l}364 \\
379\end{array}$ & $\begin{array}{c}99.11 \\
101.16\end{array}$ & $\begin{array}{l}24.30 \\
25.26\end{array}$ & 0.630 .89 & 1.171 .96 & 14.87 & 8.63 & 0.01 \\
\hline Depth of the slope $(\mathrm{cm})$ & $\begin{array}{l}\text { I } \\
\text { II }\end{array}$ & $\begin{array}{l}96.07 \\
98.27\end{array}$ & $\begin{array}{c}7.5 \\
7.43\end{array}$ & 7.497 .34 & $\begin{array}{l}-0.28 \\
-0.18\end{array}$ & $\begin{array}{l}-1.49 \\
-1.36\end{array}$ & 2.2 & 6.87 & 0.01 \\
\hline
\end{tabular}

The explosiveness of the lower limbs has been established with the "long jump with two legs" test. Both the experimental groups have improved their explosiveness, which can be affirmed by the average values of the indicator after the experimental closure. The rise (d) of the average values of the 6 year olds is $d=5.20 \mathrm{~cm}$ and $d=4.36 \mathrm{~cm}$ for the 7 year olds. It is backed up by high authenticity - $\mathrm{P}<0.01$ (Tables $1 \& 2$ and Figure 1 ). The values of the variation coefficient $\mathrm{V}$ fluctuate between $6.13 \%$ and 
$25.26 \%$ (6 year olds) and between $3.57 \%$ and $23.13 \%$ (7 year olds) (Tables $1 \& 2$ ). Therefore both the examined aggregates are reasonably homogeneous regarding the explosiveness of the lower limbs. In the end of the experiment, both extracts maintain the normal and symmetrical distribution of the sign (Tables 1 \& 2).

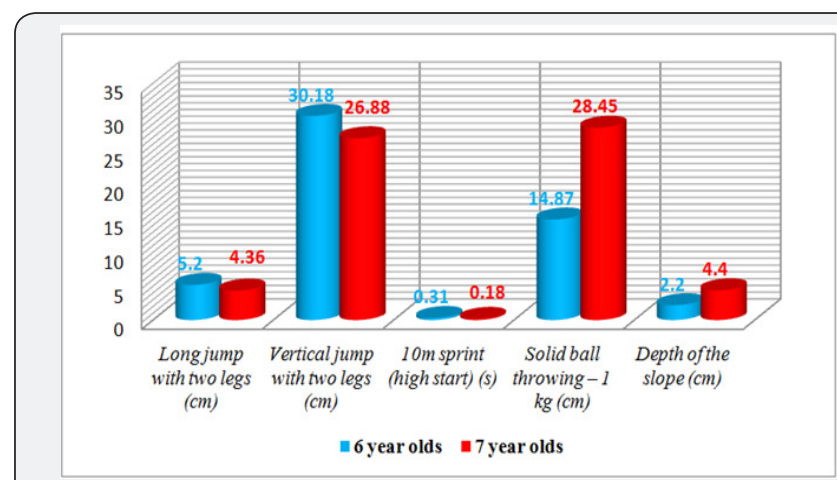

Figure 1: Significance of the rises in the average levels of the examined indicators for the period of the pedagogical experiment.

In the "vertical jump with two legs" a normal variability in both the examined groups is observed in the beginning as well as in the end of the experiment. This demonstrates the homogeneity of the extracts (Tables $1 \& 2$ ). The rise of the 6 year olds is significant Figure 1, while the 7 year olds' is not that significant, but it is backed up by the needed statistical authenticity $\mathrm{P}<0.01$ in both ages [8-11]. The rise by the 6 year olds is $30.18 \mathrm{~cm}$ and $26.88 \mathrm{~cm}$ by the 7 year olds (Tables $1 \& 2$ ). After the end of the experiment a normal distribution of the sign and symmetry are observed.

The " $10 \mathrm{~m}$ sprint (high start)" test has been applied for a greater authentication and persuasiveness (Tables $1 \& 2$ and Figure 1). Judging by the variation coefficient $V$, whose values fluctuate between $6.13 \%$ and $12.17 \%$ before the experiment, the examined groups are approximately homogeneous regarding this indicator. After the closure of the experimental influence, a rise in the average values of both the experimental groups is observed. The rise is $d=-0.31 \mathrm{~s}$ ( 6 year olds) and $d=-0.18 \mathrm{~s}$ (7 year olds). This is confirmed through the empirical values of the t-criteria of Student for independent extracts $\mathrm{P}<0.01$ in both age groups. After the end of the experimental influence the approximate homogeneity of the examined groups is maintained. The distribution of the signs is normal and symmetrical.

It can be claimed that the analyzed better results in both experimental groups are due to the mini basketball game approach education. The explosiveness of the upper limbs is examined through the "solid ball throwing $(1 \mathrm{~kg})$ " test. After the end of the experiment the average value of the 6 year olds' indicator grows up by $14.87 \mathrm{~cm}$ and a $21.6 \mathrm{~cm}$ growth is observed by the 7 year olds (Figure 1 ). The rise in both extracts is backed up by a high statistical authenticity $-\mathrm{P}<0.01$. A normal distribution of the sign for both the experimental groups in the beginning and in the end of the experiment is observed $-\mathrm{As}=0.89, \mathrm{Ex}=1.96$ ( 6 year olds) and $\mathrm{As}=-0.78, \mathrm{Ex}=-0.38$ (7 year olds) (Tables 1 \& 2).

After the end of the experimental influence, the acceptable homogeneity of this indicator in both the examined groups is maintained. It characterizes the speed and strength features of the students. The "depth of the slope" test is informative about the condition of the flexibility. It is well known that flexibility is genetically transferred and is individual. It is approximately easily teachable but also quickly lost. The observed extracts show homogeneity regarding the variation coefficient before the experiment e $<10 \%$, normal distribution of the sign and symmetry (Tables $1 \& 2$ ). The significant increase of indicators average value proves a good selection of means and methods for influence in the experimental groups regarding the development of the depth of the slope.

Tables $1 \& 2$ display that the 6 years old have increased the average values of the "depth of the slope" from $96.07 \mathrm{~cm}$ to $98.27 \mathrm{~cm}$ and the 7 years olds - from $97.53 \mathrm{~cm}$ to 101.93 . The rise by the 6 years old is $2.20 \mathrm{~cm}$ and 4.40 by the 7 years old and are both confirmed with a statistical authenticity $\mathrm{P}<0.01$ (Tables $1 \& 2$ and Figure 1). It can be claimed that in the end of the experiment the symmetry and the height of the distribution curve for this indicator is within the boundaries of the ordinary for both the experimental groups and they remain homogeneous.

\section{Conclusion}

a) After the end of the pedagogical experiment a significant rise in all five of the examined indicators for physical capability is observed. This is due to the fact that a planned and aimed mini basketball education process by the means of a game approach was conducted. It is only logical that in the end of the reviewed period better results were expected.

b) Our research shows that after the experimental influence the groups maintain their homogeneity in all of the physical capability indicators.

c) The distribution of the observed indicators in both groups remains normal and symmetrical after the experimental period.

d) The experimental method by the means of a game approach should be integrated in the practice, through which the specialized sport literature will be enriched and the work of the pedagogues and the sport specialists will be boosted.

\section{References}

1. Milena Aleksieva (2016) Changes in physical capability of 8 and 9 year old students after applying the game approach. Journal of Physical Education and Sport p. 84-87.

2. Zhelyazkov TSV, D Dasheva (2010) Sport practice basics. Gera Art p. 29. 
3. Kantcheva E, Belomazheva-Dimitrova S (2015) Working book in Methodology of Physical Education-Professional Practical Training. Veliko Turnovo p. 43-44.

4. Petkova L, M Kvartirnikova (1985) Test for physical capability evaluation. Med and physical education Sofia, p. 83.

5. Thuc DC, Danh VC (2017) Evaluating the Development about Professional Physical Fitness and Basic Techniques of Talented Male Volleyball Athletes from 12 to 13 Years Old after a Training Year pf an Giang Province. Journal Physical of Education Research 4(4): 111-116.

6. Petkova M (2014) Accents in the module education-games and badminton. Faber, p. 37-38.

7. Petkova M, Aleksieva M (2013) Games in the primary school. Faber, p. 12.
8. Dao Chanh Thuc (2017) Evaluating the Development about Professional Physical Fitness and Basic Techniques of Talented Female Volleyball Athletes from 13 to 15 Years Old after a Training Year of an Giang Province. IOSR Journal of Sports and Physical Education 5(5): 43-47.

9. Aleksieva M (2009) Influence of the specialized method for initial basketball education on the physical development and the specific performance of 6 and 7 year old boys. PhD Sofia, p. 68 .

10. Gigova V (1999) Statistical process and data analysis. Master's guide, p. $58-62$.

11. Thanh LQ, Lam NT (2001) Sports Measurement Book. Ho Chi Minh University of Sport, Viet Nam.

\section{Your next submission with Juniper Publishers will reach you the below assets}

- Quality Editorial service

- Swift Peer Review

- Reprints availability

- E-prints Service

- Manuscript Podcast for convenient understanding

- Global attainment for your research

- Manuscript accessibility in different formats ( Pdf, E-pub, Full Text, Audio)

- Unceasing customer service

Track the below URL for one-step submission https://juniperpublishers.com/online-submission.php 